\title{
The Influence of Transformational Leadership on Work Engagement and Employee Commitment
}

Benedicta Akey-Torku*, Baozhen Dai

School of Management, Jiangsu University, 301 Xuefu Road, Zhenjiang, Jiangsu, P.R. China

Corresponding Author: Benedicta Akey-Torku (benedicta_akey@yahoo.com)

\begin{abstract}
Despite the fact that leaders may be constrained as far as the structure of relational networks function restricts the flow of information, knowledge and resources, leadership is responsible to have clear insight of the goals of the organization and its administrative tasks or function,, appreciate strongly the nature of fluidity and dynamics of the social structures in the organisation and how they affect the organisation over before they can be effective. This paper investigates the relationship between transformational leadership attributes and employee's commitment. The study further investigates the extent to which work engagement mediates the relationship between transformational leadership and employee commitment. The analysis shows that the entire hypothesis must be accepted. This is because a leader's intellectual stimulation significantly influences the commitment of healthcare professionals and it's statistically significant at $95 \%$ confidence interval. The same applies to the fact that the relationship between intellectual stimulation and employee commitment is mediated by work engagement. Again the analysis accepts the fact that a leader's idealised influence significantly influences the commitment of healthcare professionals and also that the relationship between idealised influence and employee commitment is mediated by work engagement.
\end{abstract}

Keywords : Relationship, Leadership, Commitment, Engagement, Double-Loop Learning, Idealised Influence, Involvement, Loyalty, Square Regression Model

\section{INTRODUCTION}

Despite the fact that leaders may be constrained as far as the structure of relational networks function restricts the flow of information, knowledge and resources, leadership is responsible to have clear insight of the goals of the organization and its administrative tasks or function,, appreciate strongly the nature of fluidity and dynamics of the social structures in the organisation and how they affect the organisation over before they can be effective (Gulati et al., 2013; Polyhart \& Moliterno, 2016). It is this conviction that justifies the need for leaders to develop expertise and understand how people work within the social system in a functionally cohesive manner (Day et al., 2016; Lord \& Hall, 2015). Thus specific leader behaviours that may contribute to high organisational performance and effectiveness. In all instances the leader must focus on making available everything necessary to a group to make them effective and cohesive (Hackman \& Wageman, 2015). Zaccaro et al. (2014), Hackman \& Wageman (2015), Morgeson (2015)), Klein, Zeigert, Knight, and Xiao (2015) identifies five important functional leadership areas where if leaders concentrate on promoting high organizational performance. These functions include environmental monitoring, coaching and teaching subordinates, organizing subordinate activities, motivating others, and active intervention in the work of the group. 
Further, Lord and Dinh (2013) explains that ensuring leadership efficacy in leadership performance is dependent on the ability to demonstrate several leadership behaviours Fleishman's (2019) initial work noted that subordinates perceived the behaviour of their supervisors in respect of two broad categories referred to as consideration and initiating structure. By consideration, Lord and Dinh (2013) refer to those leadership behaviours aimed at fostering effective relationships. Such behaviour interventions include a show of concern for a subordinate or acting in a supportive manner towards others. On the other hand, initiating structure includes those actions of the leader that is generally focused on accomplishing task. This is usually done by setting performance standards, role clarification and holding subordinates accountable to those standards. The work of Flynn (2015) pre-empts the important question as whether functions affect identities in an organisations or the extent to which identities can serve as a mediator in that transformational leadership is supposed to influence identity level, creating a more collective identity.

As reported by Flynn (2015), there are different personal, reciprocal, generalised, relational and collective orientations and negotiated forms that can elicit a preference for a particular form of exchange that engender employee commitment. In all of these theories the evidence of the presence of condition which generated sustainable organisation effectiveness in relations to quality of leadership is emphasized. Leadership within the work place is affected and influenced by so many things in the same way organisational processes and individual employee motivation is also influenced by several factors. These must be carefully integrated into an integrated leadership module and applied to one specific industrial context such as the hospitals in Ghana to see the extent to which they are applicable or not applicable.
In order to ensure high organisation contiguity and conviviality that leads to effective performance. Other studies such as Lord and Shondrick (2016) argues that leadership processes and organisation processes are dependent on knowledge acquisition and use however this knowledge is not static but is continuously changing from emphasis on what they call classical symbolic to connectionism and most recently to an embodied, embedded view of cognition. Liu, et al (2016), also argue that effective leadership must connect all the three strand of knowledge level in order to ensure that there is effectiveness of leadership. On the other hand, Masa'deh, et al (2016) also argue that the context or processes of socialregulation including having active goals, identity, and affect and also the availability of emergent and formalized system of leadership where shared values are functional prerequisite for dynamic organizational development exist. An organisation becomes more effective when such an organisation is able to successfully adapt to organizational demands, task and social feedback, and are to provide and ambience for collective learning, transform the structural aspects through "double-loop learning" at the individual and collective learning levels (Aga, et al, 2016). The healthcare market in Ghana is one of the areas with enormous challenge when it comes to leadership. Each year there are numerous reports of employee discontent, high turnover, strikes and other industrial actions a to protest bad leadership and these come at the expense of the lives of citizens most of whom have come from very poor background to seek medical support. According to Boateng (2018) one out of every ten hospital employees studied in Ghana has had cause to complain about the quality of leadership which ultimate affects work engagement, commitment and performance. If Ghanaian hospitals are to achieve the desired goals and support the attainment of the millennium development goals, then effective and transformational leadership is an imperative factor that must be imbibed and embedded 
in the organisational culture to support the actualisation of the objectives of primary healthcare for all. It is within this dilemma that this research emerges as supporting empirical evidence on the influence of transformational leadership stimulating work engagement, commitment and performance in healthcare facilities in Ghana

This paper investigates the relationship between transformational leadership attributes and employee's commitment. The study further investigates the extent to which work engagement mediates the relationship between transformational leadership and employee commitment. The analysis involves the study validated six components of work performance to include Task performance, Contextual performance - interpersonal, Contextual performance organizational, Adaptive performance and Counterproductive work behaviour. Figure 1 shows the framework for this chapter and the corresponding hypothesis derived from them.

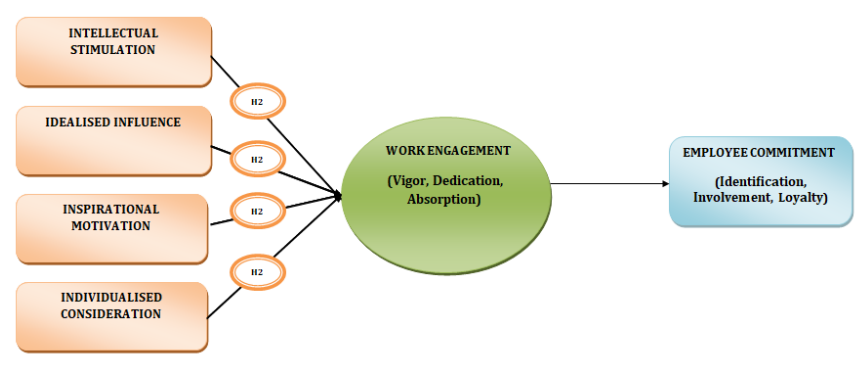

Figure 1 : Framework for the Hypotheses

* H2a: A leader's intellectual stimulation significantly influences the commitment of healthcare professionals

H2b: The relationship between intellectual stimulation and employee commitment is mediated by work engagement

H2c: A leader's idealised influence significantly influences the commitment of healthcare professionals
H2d: The relationship between idealised influence and employee commitment is mediated by work engagement

H2e: A leader's inspirational motivation significantly influences the commitment of healthcare professionals

H2f: The relationship between inspirational motivation and employee commitment is mediated by work engagement

H2g: A leader's individualised consideration significantly influences the commitment of healthcare professionals

$\mathrm{H} 2 \mathrm{~h}$ : The relationship between individualised consideration and employee commitment is mediated by work engagement

\section{METHODOLOGY}

The methodology of this study is also similar to the first methodology adopted to analyse the information in chapter six. The same sample was used and it was randomly selected. It was made up of a total of 852 respondents and a questionnaire data collection instrument was administered to them. It is necessary to emphasize that this sample was also sample selected from both clinical and non-clinical staff at four teaching hospitals in Ghana namely; the Korle$\mathrm{Bu}$ Teaching Hospital, the Komfo Anokye Teaching Hospital, the Tamale Teaching Hospital and the Cape Coast Teaching Hospital. In addition, data was also procured from the 37 Military Hospital as well as the Ho Regional Hospital. In this case also the latter hospitals were chosen due to their unique role in healthcare delivery and the volume of patients that uses the facility. As stated in earlier sections, the Ho Regional Hospital is nearing its conversion to become a teaching hospital and is actively used by the University of Health and Allied Sciences for its medical school program. Similarly, the 37 Military Hospitals is the biggest military healthcare facility in Ghana hence it is a referral hospital for the country in 
during emergency and also serves other nationals in West Africa including troops of the United Nations. Initially 1000 respondents agreed to participate in the research after preliminary consultations but only 865 returned the questionnaire. 13 questionnaires were subsequently discarded as they were not properly filled or breached essential qualification requirement. Again the respondents were largely nurses, laboratory technicians, hospital administrators, doctors, and other allied health workers in the designated hospitals. The same transformational leadership instrument was used in this case also. The constructs were Intellectual stimulation (IS) and it was measured using 8 items. The next was idealised influence (IN) and was measured with 4 items, whiles inspirational motivation (IM) was measured with 4 items. Finally individualised consideration (IC) was measured with 4 other items and all of these were based on the multifactor leadership scale. The components of work engagement were also made up of Vigour (VG), dedication (DD) and absorption (AB). The questions that were used to measure them were made up of five items each. The main difference came from the measurement of commitments. In this case the model adopted the constructs by Avioli et al (2008) that measures commitment based on identification (1F), involvement (IV) and loyalty (LT). Each of these attributes of organisational commitment was measured using the five questions as suggested by Bass et al (2018). The analytical process that was adopted in this study is the ordinary least square regression model (OLS). This model was used in this study because of its simplicity. Before the analysis, other statistical and descriptive information were also extracted and their implication for the study. Some of this important information have been summarised in subsequent sections of the study.

\section{RESULTS AND DISCUSSION}

Table 1: Gender* Age Category Crosstabulation

Count

\begin{tabular}{|ll|r|r|r|r|}
\hline & & \multicolumn{3}{|c|}{ Age Category } & \multirow{2}{*}{ Total } \\
\cline { 3 - 5 } & & \multicolumn{1}{|c|}{$18-30$} & \multicolumn{1}{|c|}{$31-40$} & \multicolumn{1}{|c}{$41-50$} & \\
\hline \multirow{2}{*}{ Gender } & Female & 122 & 212 & 212 & 546 \\
& Male & 84 & 96 & 126 & 306 \\
Total & & 206 & 308 & 338 & 852 \\
\hline
\end{tabular}

The table below presents the difference in the gender composition among the respondents. The analysis shows that 306 respondents were male while 456 of them were males. This information indicates that a reasonable percentage of male and female were selected to take part in the study.

Table 1 : Analysis of Data Variability

\begin{tabular}{|c|c|c|c|c|c|c|c|c|c|}
\hline & $\mathrm{N}$ & $\begin{array}{c}\text { Minimu } \\
\mathrm{m}\end{array}$ & $\begin{array}{c}\text { Maxim } \\
\text { um }\end{array}$ & Mean & $\begin{array}{c}\text { Std. } \\
\text { Deviati } \\
\text { on }\end{array}$ & \multicolumn{2}{|c|}{ Skewness } & \multicolumn{2}{|c|}{ Kurtosis } \\
\cline { 2 - 9 } & Statistic & Statistic & Statistic & $\begin{array}{c}\text { Statist } \\
\text { ic }\end{array}$ & Statistic & $\begin{array}{c}\text { Stati } \\
\text { stic }\end{array}$ & $\begin{array}{c}\text { Std. } \\
\text { Erro } \\
\mathrm{r}\end{array}$ & $\begin{array}{c}\text { Statist } \\
\text { ic }\end{array}$ & $\begin{array}{c}\text { Std. } \\
\text { Error }\end{array}$ \\
\hline
\end{tabular}




\begin{tabular}{|l|r|r|r|r|r|r|r|r|r|}
\hline Intellectual Stimulation & 840 & 1 & 5 & 2.18 & .136 & .112 & .084 & .566 & .169 \\
\hline Idealized Influence & 840 & 4 & 5 & 4.75 & .433 & .157 & .084 & .663 & .169 \\
\hline $\begin{array}{l}\text { Inspirational } \\
\text { Motivation }\end{array}$ & 840 & 4 & 5 & 4.71 & .452 & .950 & .084 & .099 & .169 \\
\hline $\begin{array}{l}\text { Individualized } \\
\text { Consideration }\end{array}$ & 840 & 3 & 5 & 4.39 & .618 & .499 & .084 & -.639 & .169 \\
\hline Vigour & 840 & 2 & 5 & 3.75 & .090 & .653 & .084 & .901 & .169 \\
\hline Dedication & 840 & 2 & 5 & 4.32 & .759 & .104 & .084 & .118 & .169 \\
\hline Absorption & 840 & 1 & 5 & 3.89 & .081 & .148 & .084 & .141 & .169 \\
\hline Identification & 810 & 1 & 5 & 4.02 & .081 & .274 & .086 & .225 & .172 \\
\hline Involvement & 840 & 4 & 5 & 4.68 & .467 & .766 & .084 & .416 & .169 \\
\hline Loyalty & 840 & 2 & 5 & 3.96 & .926 & .471 & .084 & .739 & .169 \\
\hline Valid N (listwise) & 810 & & & & & & & & \\
\hline
\end{tabular}

case the mean and standard deviation is 4.39 and .452

Table 6 presents the details of descriptive statistics, statistical variance and measures of central tendency for the important factors in this research. These relates to the dimensions of the transformational leadership, work engagement and commitment. The analysis shows that the mean and standard deviation of intellectual stimulation, is 2.18 and .136 respectively. This data is normally skewed (.112) and the kurtosis is .566. This confirms that employees' intellectual stimulation by their leaders is within acceptable range of normal distribution. Secondly, the analysis shows that the mean and standard deviation of idealized influence is 4.75 and .433 respectively. This data is normally distributed (.157) and the kurtosis is .663. This confirms that leader's idealised influence is within acceptable range of normal distribution.

Regarding the descriptive results of leaders' inspirational motivation in hospitals, the analysis indicates a mean and standard deviation of 4.71 and .452 respectively. Again this data is normally distributed (.950) and the kurtosis is .099. This confirms that inspirational motivation by leaders is within acceptable range of normal distribution. Similar trend is also observed regarding the individualized consideration by a leader which is the fourth attribute of transformational leadership. In this respectively. This data is evenly distributed around the mean with a skewness of .499 and the kurtosis is .639. This confirms that leaders' individualised consideration is within acceptable range of normal distribution. The next dimension that has been investigated is vigour and it is a work engagement attribute. The descriptive statistics show that the mean and standard deviation is 3.75 and .618 respectively. The skewness of (.653) and kurtosis of .901 is a good confirmation of the fact that vigour is a good component of work engagement among employees in hospitals in Ghana and is within the acceptable range of normally distribution hence the justification of a parametric analysis technique.

Regarding the level of dedication, the table shows recorded a mean and standard deviation of 4.32 and .090 respectively. This data is normally skewed (.104) and the kurtosis is .118. This means that dedication as a component of work engagement is within acceptable range of normal distribution. Similarly, the mean and standard deviation of 3.89 and .759 respectively regarding absorption as a work engagement attribute is normally distributed. The skewness of (.148) and kurtosis is .141 confirms this trend. Thirdly, the descriptive analysis indicates that identification as an organisational commitment attribute has a mean and standard deviation of 3.82 
and .081 respectively. Again this data is normally distributed with skewness of (.491) and kurtosis of .726. The next attribute of commitment is involvement and the data is evenly distributed around the mean. The skewness is .296 and the kurtosis is .636. Significantly a high mean response value of 4.11 is noted and the standard deviation is .805 . This is a justification for the use parametric techniques for further analysis. Similar trend is also observed regarding the employees' loyalty in the healthcare facilities in Ghana. In this case the mean and standard deviation is 3.61 and .724 respectively. This data is evenly distributed around the mean with a skewness of (.034) and the kurtosis is .055. This information also supports the idea that employees' evaluation of their motivation is within acceptable range of normal distribution.

Table 1 : Factor loadings

Pattern Matrix ${ }^{\mathrm{a}}$

\begin{tabular}{|c|c|c|c|c|c|c|c|c|}
\hline & & & Factor & & & & & \\
\hline & 1 & 2 & 3 & 4 & 5 & 6 & 7 & 8 \\
\hline Int. Stim & 0.83104 & & & & & & & \\
\hline Int. Stim & 0.78106 & & & & & & & \\
\hline Int. Stim & 0.73304 & & & & & & & \\
\hline Idealised Inf. & & 0.66934 & & & & & & \\
\hline Idealised Inf. & & 0.65954 & & & & & & \\
\hline Idealised Inf. & & 0.61838 & & & & & & \\
\hline Insp. Mot & & & 0.60662 & & & & & \\
\hline Insp. Mot & & & 0.59486 & & & & & \\
\hline Insp. Mot & & & 0.8624 & & & & & \\
\hline Ind. Con & & & & 0.85554 & & & & \\
\hline Ind. Con & & & & 0.80066 & & & & \\
\hline Ind. Con & & & & 0.79968 & & & & \\
\hline Vigour & & & & & 0.930 & & & \\
\hline Vigour & & & & & 3.812 & & & \\
\hline Vigour & & & & & 0.810 & & & \\
\hline Dedication & & & & & & 0.57428 & & \\
\hline Dedication & & & & & & 0.77322 & & \\
\hline Dedication & & & & & & 0.71834 & & \\
\hline Absorption & & & & & & & 0.64974 & \\
\hline Absorption & & & & & & & 0.63896 & \\
\hline Absorption & & & & & & & 0.62034 & \\
\hline Commitment & & & & & & & & 0.94668 \\
\hline Commitment & & & & & & & & 0.77126 \\
\hline Commitment & & & & & & & & 0.65954 \\
\hline Commitment & & & & & & & & 0.76636 \\
\hline Commitment & & & & & & & & 0.6174 \\
\hline Commitment & & & & & & & & 0.5733 \\
\hline
\end{tabular}

Extraction Method: Maximum Likelihood.

Rotation Method: Promax with Kaiser Normalization. 
The test of sampling adequacy is inferred from the results of the KMO Sampling Adequacy Test and Bartlet's test of Sphericity test. The two results were significant and the communalities for each of the variables (intellectual stimulation, idealized influence, inspirational motivation, individualized consideration, work engagement, commitment are sufficiently high (all of them are above 0.300 and most of them are above 0.600 ). This is indicates that the chosen variables for the analysis especially for the independent variables adequately correlated for factor analysis. In addition, the reproduced matrix had only
$2 \%$ non-redundant residuals that are greater than 0.05 and this further confirms the adequacy of the variables and the 8 factor model. The validity of the factors is also demonstrated by the sufficient convergent validity presented in the table. Not all the loadings were within acceptable range hence were dropped from the analysis. Sufficient discriminant validity is also demonstrated by all the designated because the correlation matrix presented in table 1 shows that there is no correlations above 0.700 , and there are no problematic cross-loadings.

Table 2 : Analysis of Internal Consistency Test (Cronbach's Alpha Correlation Coefficient)

\begin{tabular}{|c|c|c|c|c|c|}
\hline & $\begin{array}{l}\text { Scale Mean if } \\
\text { Item Deleted }\end{array}$ & $\begin{array}{l}\text { Scale Variance } \\
\text { if Item Deleted }\end{array}$ & $\begin{array}{l}\text { Corrected Item- } \\
\text { Total Correlation }\end{array}$ & $\begin{array}{c}\text { Squared } \\
\text { Multiple } \\
\text { Correlation }\end{array}$ & $\begin{array}{c}\text { Cronbach's } \\
\text { Alpha if Item } \\
\text { Deleted }\end{array}$ \\
\hline Intellectual Stimulation & 61.54 & 27.272 & .547 & 0.299 & .675 \\
\hline Idealized Influence & 58.94 & 33.789 & .273 & 0.075 & .714 \\
\hline Inspirational Motivation & 59.02 & 31.754 & .641 & 0.411 & .792 \\
\hline Individualized Consideration & 61.54 & 27.272 & .547 & 0.299 & .775 \\
\hline Engagement & 58.94 & 33.789 & .273 & 0.075 & .714 \\
\hline Commitment & 59.87 & 28.870 & .448 & 0.201 & .790 \\
\hline Valid N (listwise) & 59.76 & 34.865 & -.042 & 0.002 & .747 \\
\hline
\end{tabular}

Even though the data collection instrument was tested for reliability before data is collected, the response trends may equally present issues of internal consistency among the different variables that were considered in the analysis. The Cronbach alpha correlation coefficient was therefore used to determine the internal consistency of the data and for that matter the reliability of the data. According to Pallant (2006) factors with loadings lower than 0.7 must be eliminated from the analysis and this was used as the selection criteria. As noted in the table all the factors of the thirteen variables have exceed the threshold of 0.7 hence the internal consistency of the data.

Table 3 : Test of Normality Test

\begin{tabular}{|l|l|r|r|r|r|r|r|}
\hline \multirow{2}{*}{} & \multirow{2}{*}{ Gender } & \multicolumn{2}{|c|}{ Kolmogorov-Smirnov } & \multicolumn{3}{|c|}{ Shapiro-Wilk } \\
\cline { 2 - 8 } & & Statistic & \multicolumn{1}{c|}{$\mathrm{df}$} & \multicolumn{1}{c|}{ Sig. } & \multicolumn{1}{c|}{ Statistic } & \multicolumn{1}{c|}{$\mathrm{df}$} & \multicolumn{1}{c|}{ Sig. } \\
\hline $\begin{array}{l}\text { Intellectual } \\
\text { Stimulation }\end{array}$ & Male & .350 & 830 & .000 & .636 & 855 & 0.076 \\
\cline { 2 - 8 } & Female & .381 & 10 & .000 & .640 & 1 & 0.077 \\
\hline $\begin{array}{l}\text { Idealized } \\
\text { Influence }\end{array}$ & Male & .455 & 830 & .000 & .557 & 855 & 0.067 \\
\hline
\end{tabular}




\begin{tabular}{|l|l|r|r|r|r|r|r|}
\hline \multirow{2}{*}{$\begin{array}{l}\text { Inspirational } \\
\text { Motivation }\end{array}$} & Male & .291 & 830 & .000 & .761 & 855 & 0.091 \\
\cline { 2 - 7 } & Female & .381 & 10 & .000 & .640 & 1 & 0.077 \\
\hline $\begin{array}{l}\text { Individualized } \\
\text { Consideration }\end{array}$ & Male & .213 & 830 & .000 & .850 & 855 & 0.102 \\
\cline { 2 - 7 } & Female & .314 & 10 & .006 & .750 & 1 & 0.090 \\
\hline
\end{tabular}

a. Lilliefors Significance Correction

Many statistics tools can be used to detect any violation of normality assumption. For example, normal Q-Q plot, box plot, histogram and steam \& leaf for standardized residuals can be used to check the normality assumption. Reviewing these statistics tools indicates that the distribution of the residuals is not normal; positive skew of standardized residuals is 2.675 while kurtosis is 14.08 . In order to check whether this violation of normality assumption is significant or not, the researcher employs two statistical tests. Kolmogorov-Smirnov and ShapiroWilk tests are significant $(\mathrm{p}<0.001)$. Therefore, the null hypothesis that the distribution is normal is rejected. This means that residual is not normally distributed. It could be concluded that the violation of the normality assumption may have severe impact on the result. Pallant (2006) stated that 'the normality assumption, for instance, can be ignored when the sample size is large enough, for then the central limit theorem can be invoked' (Pallant (2006). Moreover, Pallant (2006) point out that the violation of normality assumption occurs when the distribution of the residuals is extremely skewed. However, the sample under investigation suffer from the small sample size $(\mathrm{n}=840)$ and the distribution of standardized residual is considerably positively skewed (2.675). Therefore, caution should be exercised in interpreting the results.

Table 4 : Test of Multicollinearity of Data

Correlations

\begin{tabular}{|ll|r|r|r|r|r|}
\hline & & \multicolumn{1}{|c|}{$\begin{array}{c}\text { Self- } \\
\text { awareness }\end{array}$} & $\begin{array}{c}\text { Self- } \\
\text { regulation }\end{array}$ & Social skills & Empathy & $\begin{array}{c}\text { Motivatio } \\
\mathrm{n}\end{array}$ \\
\hline Intellectual & Pearson Correlation & 1 & .347 & .023 & .197 & .336 \\
Stimulation & Sig. (2-tailed) & & .009 & .866 & .145 & .011 \\
& $\mathrm{~N}$ & 840 & 840 & 840 & 840 & 840 \\
Idealized & Pearson Correlation & .347 & 1 & .307 & .106 & .058 \\
Influence & Sig. (2-tailed) & .009 & & .021 & .437 & .674 \\
& $\mathrm{~N}$ & 840 & 840 & 840 & 840 & 840 \\
Individualized & Pearson Correlation & .023 & .307 & 1 & .340 & .311 \\
Consideration & Sig. (2-tailed) & .866 & .021 & & .010 & .000 \\
& $\mathrm{~N}$ & 840 & 840 & 840 & 840 & 840 \\
& Pearson Correlation & .197 & .106 & .340 & 1 & .056 \\
& Sig. (2-tailed) & .145 & .437 & .010 & & .684 \\
Intellectual & $\mathrm{N}$ & 840 & 840 & 840 & 840 & 840 \\
Stimulation & Pearson Correlation & .336 & .058 & .411 & .056 & 1 \\
& Sig. (2-tailed) & .011 & .674 & .000 & .684 & 840 \\
Engagement & $\mathrm{N}$ & 840 & 840 & 840 & 840 \\
& & &
\end{tabular}


**. Correlation is significant at the 0.01 level (2-tailed).

*. Correlation is significant at the 0.05 level (2-tailed).

In table 4, the analysis seeks to evaluate the possibility of multicollinearity in the independent variables. According to Pallant (2011), in a multiple regression, the independent must really be truly independent of each other. This implies that none of the predictor variables in the multiple regressions must be linearly predicted from the other variables with substantial degree of accuracy. Where two items or predictor variables show collinearity, they become redundant and one of them must be eliminated since the coefficient estimates of the regression can change erratically in response to minor changes in the data for the model. The statistical test of multicollinearity is the variance inflation factor or the correlation matrix. A correlation coefficient in excess of 0.5 and above is an indication of strong correlation hence one of the factors ought to be dropped. In the table the analysis shows that all the predictor variables are redundant of each other. The Pearson moment correlation co-efficient of matrix is lower than 0.5 in all cases and these are statistically significant at $95 \%$ confidence interval

Table 5 : Mann-Whitney U Test of Difference between Male and Female Respondents

\begin{tabular}{|c|c|c|c|c|}
\hline & Gender & $\mathrm{N}$ & Mean Rank & Sum of Ranks \\
\hline \multirow{3}{*}{ Idealized Influence } & Male & 546 & 382.32 & 206835.50 \\
\hline & Female & 306 & 489.58 & 146384.50 \\
\hline & Total & 852 & & \\
\hline \multirow{3}{*}{$\begin{array}{l}\text { Individualised } \\
\text { Consideration }\end{array}$} & Male & 546 & 422.69 & 228675.50 \\
\hline & Female & 306 & 416.54 & 124544.50 \\
\hline & Total & 852 & & \\
\hline \multirow{3}{*}{$\begin{array}{l}\text { Inspirational } \\
\text { Motivation }\end{array}$} & Male & 546 & 403.70 & 218400.50 \\
\hline & Female & 306 & 450.90 & 134819.50 \\
\hline & Total & 852 & & \\
\hline \multirow{3}{*}{ Intellectual Stimulation } & Male & 546 & 422.69 & 228675.50 \\
\hline & Female & 306 & 416.54 & 124544.50 \\
\hline & Total & 852 & & \\
\hline
\end{tabular}

Test Statistics ${ }^{\mathrm{a}}$

\begin{tabular}{|l|r|r|r|}
\hline & Idealised Influence & $\begin{array}{c}\text { Inspirational } \\
\text { Motivation }\end{array}$ & $\begin{array}{c}\text { Intellectual } \\
\text { Stimulation }\end{array}$ \\
\hline Mann-Whitney $U$ & 60224.500 & 71789.500 & 79694.500 \\
\hline Wilcoxon $W$ & 206835.500 & 218400.500 & 124544.500 \\
\hline$Z$ & -6.893 & -2.881 & -.373 \\
\hline Asymp. Sig. (2-tailed) & .000 & .004 & .709 \\
\hline
\end{tabular}

a. Grouping Variable: Gender

According to table 5 the generational differences moderates the acquisition of the leadership skills including transformational leadership values. Some of the existing studies have claimed that younger people are more inclined to pursue transformational leadership values whiles other have contested this view. Thus, the analysis in table $14 \mathrm{~b}$ shows the degree 
to which differences transformational leadership attributes are evident among different generation of leaders. The Kruskal Wallis test of variance shows that leaders between the ages of 18-30 were least ranked in terms of idealized influence whereas leaders between the ages of 31-40 (322.42) were the second highly ranked leaders (505.50) on the same construct. Finally, leaders above the age of 40 were the highest ranked (506.50) when it comes to idealized influence and these observations are statistically significant (see table 13b). In the second segment, the Kruskal Wallis test of variance shows that leaders between the ages of 18-30 were highly ranked in terms of idealized influence whereas leaders between the ages of 31-40 (327.04) were the second least ranked leaders (445.50) on the same construct. Finally, leaders above the age of 40 were the least ranked (585.50) when it comes to inspirational motivation and these observations are statistically significant (see table 15b). Finally, the Kruskal Wallis test of variance shows that leaders between the ages of 18-30 were the least ranked in terms of intellectual stimulation whereas leaders between the ages of 31-40 (347.81) were the second least ranked leaders (472.17) on the same construct. Finally, leaders above the age of 40 were the least ranked (500.50) when it comes to inspirational motivation and these observations are statistically significant.

Table 6 : Influence of Transformational Leadership on Employee Commitment
Paths
Hypothesis
Path Coefficient
$P$ Values
Status

$\begin{array}{lllll}\mathrm{ID} \rightarrow \mathrm{COMM} & \mathrm{H} 2 \mathrm{a} & 0.6408 & 0.011 & \text { Acceptable } \\ \mathrm{ID} \rightarrow \mathrm{WE} \rightarrow \mathrm{WP} & \mathrm{H} 2 \mathrm{~b} & 0.3372 & 0.031 & \text { Acceptable } \\ \mathrm{IN} \rightarrow \mathrm{WP} & \mathrm{H} 2 \mathrm{c} & 0.5652 & 0.021 & \text { Acceptable } \\ \mathrm{IN} \rightarrow \mathrm{WE} \rightarrow \mathrm{WP} & \mathrm{H} 2 \mathrm{~d} & 0.336 & 0.000 & \text { Acceptable } \\ \mathrm{IS} \rightarrow \mathrm{WE} & \mathrm{H} 22 & 0.6336 & 0.001 & \text { Acceptable } \\ \mathrm{IS} \rightarrow \mathrm{WE} \rightarrow \mathrm{WP} & \mathrm{H} 2 \mathrm{f} & 0.3492 & 0.000 & \text { Acceptable } \\ \mathrm{IC} \rightarrow \mathrm{WE} & \mathrm{H} 2 \mathrm{~g} & 0.5904 & 0.011 & \text { Acceptable } \\ \mathrm{TL} \rightarrow \mathrm{WE} \rightarrow \mathrm{WP} & \mathrm{H} 2 \mathrm{~h} & 0.6948 & 0.031 & \text { Acceptable }\end{array}$

Table 5 provides the results of the regression analysis between attributes of transformational leadership, work engagement and work productivity. The analysis shows that the entire hypothesis must be accepted. This is because a leader's intellectual stimulation significantly influences the commitment of healthcare professionals and it's statistically significant at $95 \%$ confidence interval. The same applies to the fact that the relationship between intellectual stimulation and employee commitment is mediated by work engagement. Again the analysis accepts the fact that a leader's idealised influence significantly influences the commitment of healthcare professionals and also that the relationship between idealised influence and employee commitment is mediated by work engagement. The remaining hypotheses that are accepted include the postulation that a leader's inspirational motivation significantly influences the commitment of healthcare professionals. It is significance at $95 \%$ confidence interval. The analysis of the results also shows that the relationship between inspirational motivation and 
employee commitment is mediated by work engagement. The same trend is seen when the analysis was done regarding the extent to which a leader's individualised consideration significantly influences the commitment of healthcare professionals. Finally at $95 \%$ confidence interval, it is accepted that the relationship between individualised consideration and employee commitment is mediated by work engagement.

\section{ACKNOWLEDGEMENTS}

We are grateful to the National Nature Science Foundation of China (71774069) and the Department of Public Management for their support.

\section{REFERENCES}

[1]. Adair, John (2016). Leadership and motivation: the fifty-fifty rule and the eight key principles of motivating others. Kogan Page Publishers: Philedelphia, USA \& London, UK.

[2]. Adame-Sanchez, C., Gonzalez-Cruz, T. F., \& Martínez-Fuentes, C. (2016). Do firms implement work-life balance policies to benefit their workers or themselves? Journal of Business Research, 69(11), 5519-5523.

[3]. Aga, D. A., Noorderhaven, N., \& Vallejo, B. (2016). Transformational leadership and project success: The mediating role of team-building. International Journal of Project Management, 34(5), 806-818.

[4]. Aldag, R. J. \& Kuzuhara, L. W. (2016). Organizational behavior and management: an integrated skills approach. South-Western: Thomson Learning.

[5]. Alvesson, M., \& Kärreman, D. (2016). Intellectual failure and ideological success in organization studies: The case of transformational leadership. Journal of Management Inquiry, 25(2), 139-152.
[6]. Ariely, Dan, Bracha, Anat and Meier, Stephan (2016). Doing good or Doing well? Image motivation and monetary incentives in behaving prosocially, IZA Discussion Paper No. 2968; FRB of Boston Working Paper No. 07-9. Available at SSRN: http://ssrn.com/abstract=1010620

[7]. Asrar-ul-Haq, M., \& Kuchinke, K. P. (2016). Impact of leadership styles on employees' attitude towards their leader and performance: Empirical evidence from Pakistani banks. Future Business Journal, 2(1), 54-64.

[8]. B'enabou, Ronald and Tirole, Jean (2016), Intrinsic and Extrinsic Motivation. Review of Economic Studies, Vol. 70, PP: 489-520.

[9]. Banks, G. C., McCauley, K. D., Gardner, W. L., \& Guler, C. E. (2016). A meta-analytic review of authentic and transformational leadership: A test for redundancy. The Leadership Quarterly, 27(4), 634-652.

[10]. Barbuto Jr., John E., Trout, Shirley K. and Brown, Lance L. (2016), Identifying sources of motivation of adult rural workers. Journal of Agricultural Education, Vol. 45 (3), PP: 10-21.

[11]. Batt, R., \& Valcour, P. M. (2013). Human resources practices as predictors of work-family outcomes and employee turnover. Industrial Relations: A Journal of Economy and Society, 42(2), 189-220.

[12]. Baumert, Jurgen and Demmrich, Anke (2015). Test motivation in the assessment of student skills: The effects of incentives on motivation and performance, European Journal of Psychology of Education, Vol. 16(3), PP: 441462.

[13]. Beauregard, T. A. (2014). Fairness perceptions of work- life balance initiatives: Effects on counterproductive work behaviour. British Journal of Management, 25(4), 772-789.

[14]. Becker, Howard S., The epistemology of qualitative research. University of Chicago 
Press, 2014. 53-71. [from Ethnography and human development : context and meaning in social inquiry / edited by Richard Jessor, Anne Colby, and Richard A. Shweder] OCLC 46597302

[15]. Bloom, P. (2016). Work as the contemporary limit of life: Capitalism, the death drive, and the lethal fantasy of 'work-life balance'. Organization, 23(4), 588-606.

[16]. Borah, N., \& Bagla, N. (2016). Work-Life Balance: Assessing Perceptions. SCMS Journal of Indian Management, 13(3).

[17]. Bosch, C., \& Rexroth, M. (2014). Mindfulness as a cognitive-emotional segmentation strategy: An intervention promoting work-life balance. Journal of Occupational and Organizational Psychology, 87(4), 733-754.

[18]. Bouget, D., Spasova, S., \& Vanhercke, B. (2016). Work-life balance measures for persons of working age with dependent relatives in Europe. A study of national policies.

[19]. Braun, S., \& Peus, C. (2016). Crossover of Work-Life Balance Perceptions: Does Authentic Leadership Matter?. Journal of Business Ethics, 1-19.

[20]. Breevaart, K., Bakker, A., Hetland, J., Demerouti, E., Olsen, O. K., \& Espevik, R. (2014). Daily transactional and transformational leadership and daily employee engagement. Journal of occupational and organizational psychology, 87(1), 138-157.

[21]. Brewer, C. S., Kovner, C. T., Djukic, M., Fatehi, F., Greene, W., Chacko, T. P., \& Yang, Y. (2016). Impact of transformational leadership on nurse work outcomes. Journal of advanced nursing, 72(11), 2879-2893.

[22]. Brewer, C. S., Kovner, C. T., Djukic, M., Fatehi, F., Greene, W., Chacko, T. P., \& Yang, Y. (2016). Impact of transformational leadership on nurse work outcomes. Journal of advanced nursing, 72(11), 2879-2893.
[23]. Brewer, C. S., Kovner, C. T., Djukic, M., Fatehi, F., Greene, W., Chacko, T. P., \& Yang, Y. (2016). Impact of transformational leadership on nurse work outcomes. Journal of advanced nursing, 72(11), 2879-2893.

[24]. Browning, H. W., Torain, D. J., \& Patterson, T. E. (2016). Collaborative healthcare leadership: A six-part model for adapting and thriving during a time of transformative change. Center for Creative Leadership White Papers.

[25]. Buchheit, S., Dalton, D. W., Harp, N. L., \& Hollingsworth, C. W. (2015). A contemporary analysis of accounting professionals' work-life balance. Accounting Horizons, 30(1), 41-62.

[26]. Buhler, P. M. (2016). Managing in the new millennium: 21st century organizations: Everyone doing more with less. Supervision. Retrieved 14th July 2011, from http://findarticles.com/p/articles/mi_hb5020/is_ /ai_n18217632

[27]. Cameron, Judy, Banko, Katherine M. and Pierce, W. David (2015). Pervasive negative effects of rewards on intrinsic motivation: The myth continues, The Behavior Analyst, Vol. 24(1), PP: 1-44.

[28]. Cannizzo, F., \& Osbaldiston, N. (2016). Academic work/life balance: a brief quantitative analysis of the Australian experience. Journal of Sociology, 52(4), 890-906.

[29]. Careau, E., Biba, G., Brander, R., Van Dijk, J. P., Verma, S., Paterson, M., \& Tassone, M. (2014). Health leadership education programs, best practices, and impact on learners' knowledge, skills, attitudes, and behaviors and system change: A literature review. Journal of Healthcare Leadership, 6, 39-50.

[30]. Carvalho, V. S., \& Chambel, M. J. (2016). Perceived high-performance work systems and subjective well-being: Work-to-family balance and well-being at work as mediators. Journal of Career Development, 43(2), 116-129. 
[31]. Chan, X. W., Kalliath, T., Brough, P., Siu, O. L., O'Driscoll, M. P., \& Timms, C. (2016). Workfamily enrichment and satisfaction: the mediating role of self-efficacy and work-life balance. The International Journal of Human Resource Management, 27(15), 1755-1776.

\section{Cite this article as :}

Benedicta Akey-Torku, Baozhen Dai, "The Influence of Transformational Leadership on Work Engagement and Employee Commitment", International Journal of Scientific Research in Science and Technology (IJSRST), Online ISSN : 2395-602X, Print ISSN : 23956011, Volume 7 Issue 1, pp. 71-83, January-February 2020. Available at doi : https://doi.org/10.32628/IJSRST207118 Journal URL : http://ijsrst.com/IJSRST207118 